\title{
Financial Education: an experience with 3rd Grade students
}

\section{Educación financiera: una experiencia con alumnos de $3^{\circ}$ de primaria}

DOI: $10.46932 /$ sfjdv2n3-019

Received in: May 1st, 2021

Accepted in: Jun 30th, 2021

\author{
Isabel Martins \\ Master in Pre-school and Primary School Education \\ Avenue Capitão Gaspar de Castro, \\ Polytechnic Institute of Viana do Castelo, School of Education \\ E-mail: isabelfalcaomartins@ hotmail.com \\ Lina Fonseca \\ Ph.D. in Didactics of Mathematics \\ Avenue Capitão Gaspar de Castro, \\ Polytechnic Institute of Viana do Castelo, School of Education \\ E-mail: linafonseca@ese.ipvc.pt
}

\begin{abstract}
Financial education is a subject that has been developing in schools with younger pupils, as they become active consumers, even at an early age. For this reason, they must gain knowledge and develop financial skills, which will enable them to acquire financial competencies. With the theme of financial education, it is intended that citizen be trained to be able to act consciously and responsibly in the financial sphere and, consequently, maintain a healthy and balanced relationship with money. Thus, it is essential to provide individuals, all of them, with knowledge and skills that allow them to respond effectively to everyday financial situations, even the simplest and most routine ones.
\end{abstract}

Keywords: financial literacy, financial education, didactic proposal.

\section{RESUMEN}

La educación financiera es una asignatura que se ha ido desarrollando en las escuelas con los alumnos más jóvenes, ya que se convierten en consumidores activos, incluso a una edad temprana. Por ello, es necesario que adquieran conocimientos y desarrollen habilidades financieras, que les permitan adquirir competencias financieras. Con el tema de la educación financiera, se pretende formar a los ciudadanos para que sean capaces de actuar de forma consciente y responsable en el ámbito financiero y, en consecuencia, mantener una relación sana y equilibrada con el dinero. Así, es fundamental dotar a los individuos, a todos ellos, de conocimientos y habilidades que les permitan responder eficazmente a las situaciones financieras cotidianas, incluso a las más simples y rutinarias.

Palabras clave: alfabetización financiera, educación financiera, propuesta didáctica.

\section{INTRODUCTION}

With greater incidence since the global financial crisis, which hit the world from 2008 on, Financial Education (FE) has received great prominence, nationally and internationally, insisting on the 
importance of empowering citizens financially, in order to ensure that they maintain a healthier and more appropriate relationship with money (Portugal Bank, 2010; McCormick, 2009; OECD, 2005).

The need for this intervention is since citizens are becoming effective consumers at an increasingly younger age. The main objective of FE to be worked on in schools is to develop each citizen's financial capabilities and to manifest them in actions, showing financial competence. This training must occur from an early age to provide each generation with a multiplier effect of information and training for themselves and their families (DGE, 2014).

Carvalhal, Tavares, and Sequeira (2012) argue that it is essential to equip students with knowledge and know-how and infuse them with analytical skills that will enable them to make financial decisions consciously and responsibly. Thus, FE becomes a fundamental aspect of individual and social education by equipping citizens with knowledge and skills that allow them to respond effectively to everyday situations.

As FE an area derives from Citizenship Education and assumes a transversal character to the curriculum, the Financial Education Referential (REF) (MEC, 2013) was created, as well as the Financial Education Booklet (MEC, 2015), to support teachers in operationalizing this topic in the classroom. For this reason, both were base documents in conducting this experiment.

In order to increase the financial literacy levels of students from a 3rd-grade class (ages 8 to 9), we tried to understand what knowledge they acquired following the implementation of a didactic proposal, which was based on the REF.

To guide the whole experience, research questions were defined: (1) What are the students' conceptions and practices regarding FE? (2) What knowledge and difficulties do students reveal in relation to the assignment performed, as well as what attitudes and behaviors do they manifest?

\section{FINANCIAL EDUCATIONS}

Considering the context of the current economic crisis, the constant fluctuation of financial markets, and the SARS-CoV-2 pandemic situation, it becomes really necessary to empower citizens so that they can move more skillfully in their society (ASIC, 2003; Campos, 2013) by having necessary skills, and part of this training is obtained through PE (Huston, 2010).

There are many definitions of FE in the literature, and it is, therefore, a non-universal and even relative concept. In the case of this study, we adopted the concept of the National Foundation for Educational Research, proposed by Schagen (1997) and cited by Banco de Portugal (2010), in which PE is understood as the ability to make informed judgments and effective decisions regarding the use and management of money. Any citizen needs to be able to transform information into knowledge, knowledge 
into a decision, and decision into action (Alves, 2012). To do so, they must have developed skills and knowledge that enable them to make assertive, responsible, and conscious choices (Huston, 2010).

The purpose of financial education is to contribute to the formation of responsible, autonomous, supportive citizens who know and exercise their rights and duties and who are critical because in addition to knowledge it requires skills and attitudes of participation (DGE, Education for Citizenship, s.d). As Citizenship Education is a cross-curricular component, which should be included and articulated with all curriculum areas, it is on it that PE should be based. It is a process by which individuals improve their understanding of financial concepts, products, and services, their financial literacy. With financial education, it is not intended to train experts in the financial field, but to provide information, training, and guidance to favor the acquisition of financial knowledge and skills to form competent citizens (Alves, 2012; Government of Brazil, 2013; OECD, 2005), equipping individuals with financial skills that will allow them to essentially improve their decision-making abilities (Alves, 2012; CCSF, 2008-2009). Based on the above, FE has become more than ever a necessary prerequisite for any citizen.

Based on the above, FE has become more than ever a necessary prerequisite for any citizen. It is in the family that the construction of the first knowledge must be based, and it is the parents, or whoever replaces them, who are the first models for their children. The relationship of parents or educators to money strongly influences the beliefs and behaviors of their children or pupils. Sometimes there is a need for the school to take the lead in this training. It will be the teachers' responsibility to help students acquire knowledge and skills, to be autonomous, to get clarifications, to be realistic when it comes to consumption, all necessary aspects to ensure their financial balance (Comission des valeurs mobilières du Manitoba, s.d.), or continuing the learning started in the family (Fonseca, Barbosa, Gonçalves, Barbosa, \& Peixoto, 2015). Both parents and teachers should provide a healthy and balanced relationship with money, and this process encompasses four major areas: (a) how to earn; (b) how to save; (c) how to spend; (d) how to give (d'Aquino, 2008).

The Mathematics Program for Elementary Education (2013) is not ambitious in connecting mathematics with financial education. While the contribution of mathematics is essential, it is not sufficient to promote students' financial literacy.

\section{FINANCIAL LITERACY AND EDUCATION IN THE NATIONAL AND INTERNATIONAL CONTEXT}

Several international and national initiatives, such as opinions, recommendations, projects, platforms, and digital portals, have been launched to promote and develop citizens' financial literacy. To promote it, several countries have created strategies to analyze and develop the financial literacy of the 
population, both nationally and internationally.

Since 2011, Portugal has presented its strategic plan: the National Financial Training Plan, whose mission is to contribute to raising the level of financial knowledge of the Portuguese population, promoting the adoption of appropriate behaviors (Banco de Portugal, 2011). Highlights as products of this national strategy are the Financial Education Benchmark (MEC, 2013), the Financial Education Notebooks (MEC, 2015), the survey conducted by the Bank of Portugal to analyze the financial literacy levels of the population (Bank of Portugal, 2010), as well as some initiatives from educational and banking institutions.

\section{METHODOLOGY}

Given the above and the objective and questions we wanted to answer, we developed a qualitative study, exploratory in nature, since we wanted to gain knowledge about a little-explored theme. The exploratory nature of this research is rooted in the fact that it addresses a subject relatively little worked, the promotion of PE with students of the 1st CEB, specifically with a 3rd-grade class, based on the REF (MEC, 2013). It also served to become more familiar with the phenomena alluding to the theme in question.

The participants in the study were a class of 20 students, 15 female, and 5 male, in the 3rd grade. Two students were diagnosed with Special Educational Needs and benefited from a completely individualized work plan. One of them was at the 1st-grade level, so he was not included in the study.

Of the 19 participants, not all saw mathematics with "good eyes". It was loved by some and hated by others, swinging their opinions from one extreme to the other. The group was dynamic, motivated, curious, with an insatiable desire to learn, to face challenges, and with a great capacity for memorization and reflection. As far as financial knowledge and notions are concerned, since the students were between 7 and 9 years old, they already brought knowledge, mostly acquired in the family. The study lasted about three months.

Several techniques were used for data collection, varying the sources of information used, to answer the research questions more effectively. The different sources made it possible to triangulate the data. This was intended to support a more reliable analysis of the data collected. Written records were collected from the students, consisting of their answers to different assignment that were part of the didactic proposal designed and implemented. We also used questionnaires and interviews.

To analyze the data, categories were defined that emerged from the data itself and the questions initially formulated. The categories established were: (a) relations established with FE; (b) students' involvement in the assignment - knowledge, and attitudes; (c) potentialities and limitations of the didactic 
proposal. Descriptors were defined for each one.

\subsection{DIDACTIC PROPOSAL}

The didactic proposal designed was based on a sequence of assignment. It was intended that the assignment would arouse the curiosity of the students, and even of their families, so that they would deconstruct some ideas and build new knowledge, alerting consciences and, through reflection, perhaps contributing to start changing mentalities.

This proposal began with the presentation of the Saves, a mascot that guided all the assignment performed and served as a source of motivation. Thus, eleven sessions were organized, and eighteen assignments were performed. The implemented sessions aimed to analyze some ideas regarding money and its management, to introduce and connect new concepts and knowledge, to reflect on and discuss various financial issues, to exchange ideas, to share experiences, and to record reasoning.

\section{PRESENTATIONS AND RESULTS ANALYSES}

\subsection{ASSIGNMENT - LET'S GO SHOPPING!}

Articulating with the theme addressed during the week of these implementations, the past of the local environment, a task was organized in which the group appears highlighting some characteristic aspects of the region, including costumes, handicrafts, among others. At the end of this 'trip', Big Bird, with a hearty appetite, challenges the students to cook a typical regional dinner. Poupas wanted rojões (a typical dish from Minho) and for dessert, he wanted sweet rice. The students had to buy the ingredients to make the dessert. Based on this challenge, the students had to do some shopping at the 'supermarkets' present in the classroom, the Poupa Aqui and Há de tudo (Figure 1).

Figure 1. Supermarket's Poupa Aqui and Há de Tudo (Martins, 2016, p. 85)

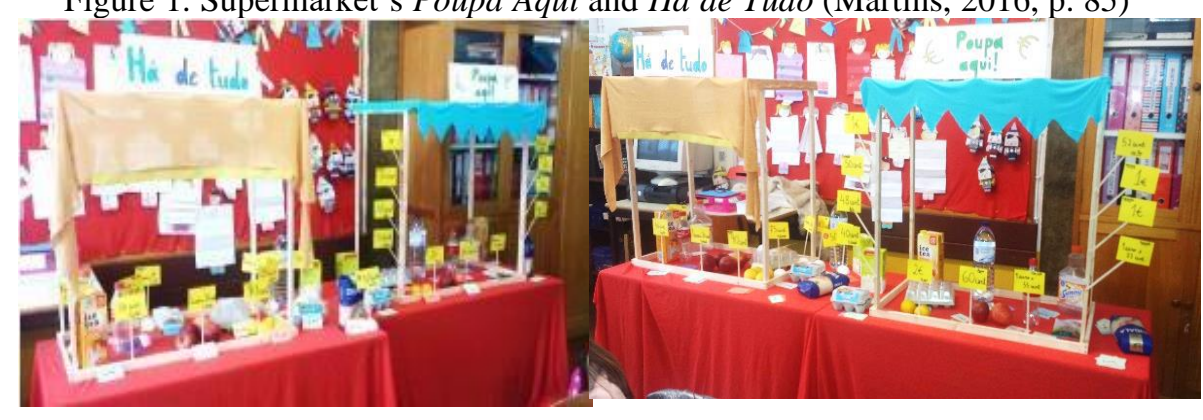

Each pair of students received $€ 10$, to make the necessary purchases for the dessert requested by the Savers. With the surplus they would do whatever they wanted: either spend or save.

Each group received the recipe and a sheet of paper to previously record their shopping list. Planning is important to prevent any unnecessary expenses and to estimate the amount to spend. 
The students had information about the prices, of the products needed, in the two supermarkets. Each group would choose where to buy. If they had always chosen the lowest price, they would have spent $€ 6.80$, and if they had chosen the highest price, they would have spent $€ 8.45$ ! However, some groups spent $€ 9.80$, as illustrated in Figure 2. Since they did not explain the calculations, which had been requested, the difference may be due to miscalculations.

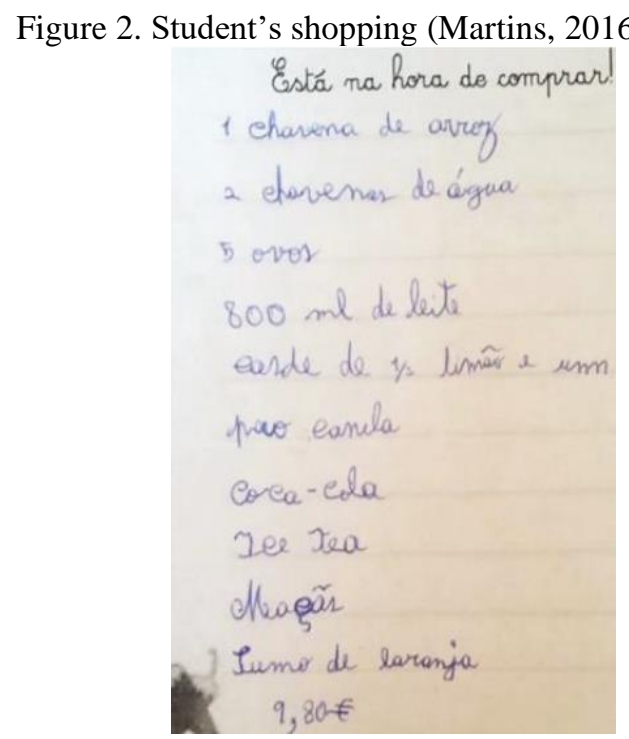

The results showed that the students did not take into account the difference in prices between the two supermarkets, which would have allowed them to buy some goods in one supermarket and others in the other. His estimation of results also revealed that it was not a usual task.

As they finished their shopping lists, the students went to the supermarkets to make their purchases. The calculations made regarding the value of the purchases and the change to be received should be confirmed (Figure 3).

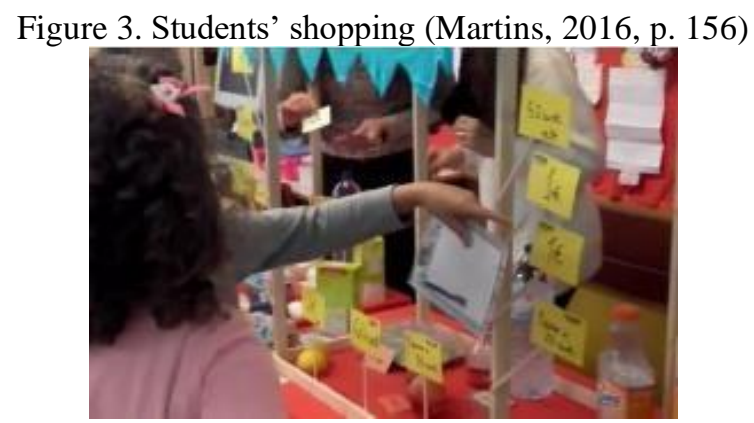

In the role of salesperson were the teachers. At this stage we noticed the use of several subtraction strategies: take away and complete.

PE - Now the total amount of purchases is 6 euros and 70 cents. 
(RD hands over a tenner)

PE - Here it is, 3 euros and 30 for change. Is that right?

RD student - (pauses to think) Yes.

PE - How did you think?

RD student - I thought that ten euros minus six gives 4 euros and 4 euros minus 70 cents gives 3 euros and 30.

EP - Great! And have you checked if I really gave 3 euros and 30 cents?

MG - Yes! That's right!

PE - That's 8 euros and 90 cents please.

Student GV - I'll pay with 10 euros.

EP - (Giving out change) Now, 1 euro and ten for change. Now, don't forget to check! I might have made a mistake!

Pupil LT - Just add up the 8 and 90 plus the change!

PE - And how much does the result have to be?

Student LT - 10! Because that's the money we had before we bought it! (Martins, 2016, pp. 157158)

After the shopping, the students were to reflect on their choices. (Martins, 2016, p. 158). About what they bought, where they bought it and why. Some groups bought from both supermarkets, justifying their choice by saying "we bought what was cheaper (...) because that way we spent less money" (Martins, 2016, p. 158). Asked why they spend less, they readily responded:

CP Student - Because we have to save!

PE - Okay, saving is very important, but for what? Why is it important to save money?

Student JP - So that we can buy what we need.

Pupil IC - And also some things we want! (adds quickly) (Martins, 2016, p.158)

To systematize the idea of income/budget, expenditure, and savings, the students filled out a table. When asked easily answered "Student TM - [Budget]. It's the money we receive. Pupil CR - So here we have to put $10 €$, it's the same for everyone! (...) IC pupil - The saving, it's what we still have! Pupil LT It's what we don't spend. (Martins, 2016, p. 160). They identified the most thrifty group and discussed the differences in the shopping behaviors of these groups. "Student IC - Oh because they only bought what was really necessary!" (Martins, 2016, p. 161).

One of the students showed the power of observation, analysis, and critical sense regarding the name of the supermarkets "The names should just be backward because Save Here is more expensive than There's Everything!" (Martins, 2016, p.159). This intervention was the motto for talking about advertising. 
We tried to awaken the students to the power of advertising, which can lead to purchases that are not always useful or necessary, and sometimes lack quality.

To understand the means used by the producers/sellers the students were challenged to create, as a family, any product, think about the advertising campaign to present to the class. The goal of advertising is to convince others to buy.

\subsection{ASSIGNMENT - FAMILY CHALLENGE}

"1. Think or imagine a product you love (if it is invented by you you should draw a picture to present to the class). It will be easier to excite and convince others if you are talking about a product you really like. Remember: the purpose of advertising is to convince others to buy or do something.

2. Who is the buyer (your target audience)? You need to try to think like him, put yourself in his position. For example: is the buyer a teenager, an adult, or a child? Is he someone who likes sports, new technologies, or fashion?

3. Agora que já escolheste o produto e o público-alvo desse produto, imagina que precisas de convencer os teus amigos a usá-lo ou a comprá-lo. What are the greatest qualities of your product? Why should they buy it? What is it good for? (Remember that sometimes what the advertisements say doesn't correspond to reality, the defects are hidden. Remember the case of the 'Save Here' supermarket where the prices were higher even though it seemed otherwise).

This is what you need to tell the audience, in a few words! Be creative!" (Martins, 2016, p. 331). The task was welcomed by the students. Two of the proposals are presented.

\subsection{THE SPECIAL CUPS - SD STUDENT PROJECT}

Toothbrush holders, with removable bottom for effective sanitation, because water does not accumulate in the cups or on the brushes. The glasses decorated the bathroom. Important aspect: the savings on brushes. The qualities of the product were highlighted, with emphasis on saving money and the environment by reducing the consumption of plastics. As the presentation was clear, direct, and enticing several classmates wanted to buy the product. The teacher used the moment to emphasize the importance of a good presentation. 
Figure 4. Special Cups Project (Martins, 2016, p. 179)

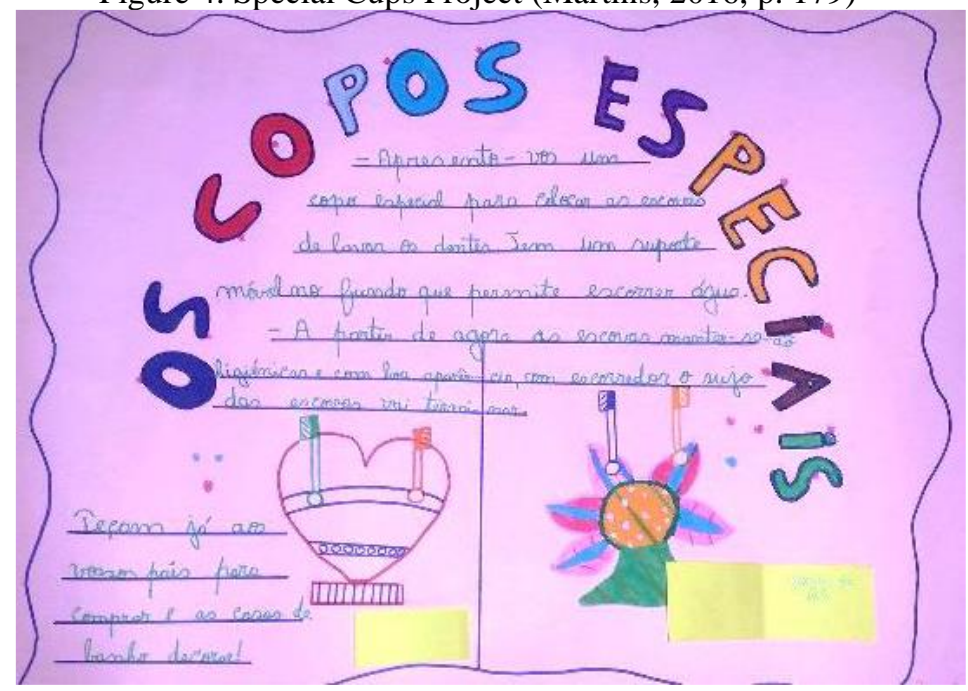

\subsection{THE TPC MAKING MACHINE - LT STUDENT PROJECT}

The presentation of this project met the students' interests!

LT Student: Before I introduce you to my project, I want to ask you a question: Did you guys want to go to the movies this afternoon?

Several students: Yes!

Student LT: Except you have homework to do, right?

Several students: Yes... (clearly less enthusiastic)

Student LT: So why don't they use this homework machine instead? (Presented his project to the class).

Several students: YESS!!! (laughs)

Student LT: All you have to do is program it into this remote (by checking it in the picture) and it does everything by itself and it is also solar powered, so you might as well have it by the window! (laughs)

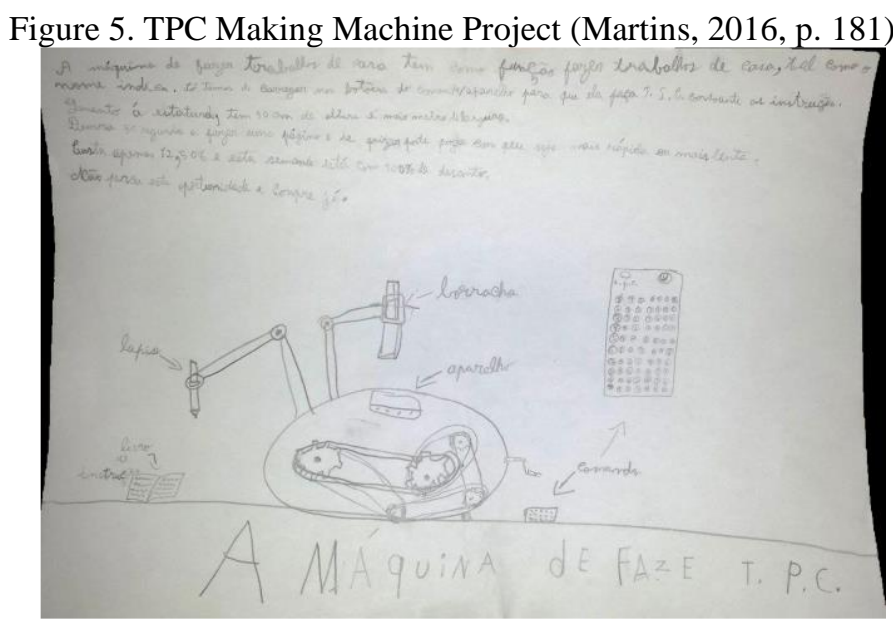

Despite the students' enthusiasm, a question was asked, "But it has to be programmed to our 
handwriting" (Martins, 2016, p. 180). The proposer had not thought of this aspect but promptly replied "it has a button on the remote that programs all the different letters" (Martins, 2016, p. 180). The students were thrilled with the LT proposal and the way it was presented! The presentation focused on identifying an unavoidable need: doing homework. The product obviated this need.

\section{A FEW CONCLUSIONS}

Most students expressed a positive attitude towards the topic of PE, attributing importance to it (OECD, 2005). They had some prior knowledge, implicit in their testimonies. They mentioned that money did not fall from the sky, nor did it grow on trees. It served various purposes, as well as for saving. Almost all reported having a piggy bank, although they did not systematically receive pocket money or pocket money. However, the money in their piggy banks was managed by their parents. They did not experience the possibility of deciding how to spend even small amounts. This aspect leads to little autonomy and difficulties in making decisions (Alves, 2012; d'Aquino, 2008) when shopping, as was evident in the task Let's go shopping! Their vocabulary about PE improved throughout the tasks.

Throughout the study, students realized the need to be cautious, heed the tricks of advertising, and responsible in their purchases (d'Aquino, 2008) to fulfill their needs. The students' behaviors differ, with some paying close attention to the price of the products, buying only the essentials and choosing where to shop, and others spending almost all their money and visiting only one supermarket. Some aspects, like advertising, need more opportunities to explore.

\section{FINALS CONSIDERATIONS}

From the study, it was possible to verify a positive evolution of the students, regarding their PE knowledge, attitudes, and behaviors. The approach chosen was an asset, even though it was the students' first formal contact with the theme because they improved in their knowledge and in the attitudes they revealed. The theme aroused their curiosity and interest, and the didactic proposal was well-received. Even the less participative students showed interest, involving themselves in the proposed tasks with attachment and enthusiasm.

We conclude that it is essential to focus on strengthening financial education at school, especially geared towards developing financial literacy in the younger generation. This requires the introduction of this theme in school curricula, but also in teacher training.

Even in the area of mathematics, simply doing mathematical tasks with the magnitude of money does not mean the development of the topic of financial education. Its concepts and notions must be worked on, involving several disciplinary areas, continuously over time and with increasing complexity. 


\section{REFERENCES}

Alves, J. (2012). Population Financial (i)literacy - A case study for a population in Northern Portugal. Master's thesis in Accounting and Finance, Institute of Accounting and Administration of Porto, Polytechnic Institute of Porto,Porto, Portugal.

https://recipp.ipp.pt/bitstream/10400.22/1179/1/DM_JoseAlves_2012.pdf

ASIC (2003). Consultation Paper 45. Financial Literacyin Schools. Australian Securities \& Investments Comission. http://download.asic.gov.au/media/1924489/what-do-you-want-to-do-with-fin-lit-schoolsdp.pdf

Campos, A. (2013). Investigating how Critical Financial Education can contribute to young consumerindividuals' consumption decisions (JIC'S). Master's thesis in Mathematics Education, Federal University of Juíz de Fora, Juíz de Fora, Brazil.

http://www.ufjf.br/mestradoedumat/files/2011/05/Dis serta\%C3\%A7\%C3\%A3o-Andre-Campos.pdf Carvalhal, A., Tavares, C. \& Sequeira, S. (2012). TeachFin€ - creative practices. Curriculum Development and Didactics. Indagatio Didactics, 4, 24- 26.

Portugal's Bank (2010). Report on the Financial Literacy Survey of the Portuguese Population. Portugal: http://clientebancario.bportugal.pt/pt-PT/Noticias/Documents/RelatorioInqueritoLiteraciaFi nanceira.pdf

Portugal's Bank (2011). National Financial Training Plan 2011-2015. Portugal:

https://www.bportugal.pt/sites/default/files/anexos/do cumentos-elacionados/intervpub20111111.pdf

CCSF (2008-2009). Rapport Annuel 2008-2009. L'éducation Financière et l'école. Comité Consultatif du Secteur Financier. Chapitre 8, 121-130.

Comission des valeurs mobilières du Manitoba (s.d.).Guide de l'instructeur en gestion financière chez lesjeunes - soyex un mentor financier.http://www.mymoneycoach.ca/sites/default/files/Mak e-it-CountInstructor-Guide-French-MSC.pdf

d'Aquino, C. (2008). Financial Education. How to educate your children. Elsevier.

DGE (s.d.). Citizenship Education. Portugal:http://www.dge.mec.pt/educacao-para-cidadania

DGE (2014). Financial Education in Schools: The Benchmark of Financial Education and Teacher

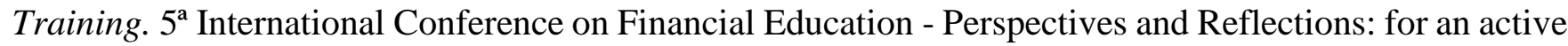
citizenship. University of Aveiro, Aveiro.

Fonseca, L., Barbosa, A., Gonçalves, T., Barbosa, G., \&Peixoto, A. (2015). Entrepreneurship Education: a path to Financial Education? 2nd Research Seminar on School Financial Education and Mathematics Education (pp.40-49). Lisbon: New University of Lisbon, Faculty of Sciences and Technology, Research and Development Unit.

Brazil's Government (2013). National Strategy for Financial Education. Guidance for Financial Education in Schools. http://www.vidaedinheiro.gov.br/docs/PlanoDiretorE NEF1.pdf

Huston, S. J. (2010). Measuring Financial Literacy. The journal of Consumer Affairs, 44, 2, 296-316. 
Martins, I. (2016). A Trail Through Financial Education: implementing a teaching proposal based on the $R E F$. Final Report of the Supervised Teaching Practice of the Master's Degree in Pre-school Education and Teaching in the 1st Cycle of Basic Education, Viana do Castelo School of Education.

McCormick, M. H. (2009). The effectiveness of youthfinancial education: A review of the literature. Journal of Financial Counseling and Planning, Vol 20, Issue 1.

MEC (2013). Referencial de Educação Financeira para a Educação Pré-Escolar; o Ensino Básico; o Ensino Secundário e a Educação e Formação de adultos. Direção Geral da Educação.

MEC (2015). Financial Education Booklet 1. Thirty for One Line.

OECD (2005). Les Principes et les Bonnes PratiquesRelatifs à la Sensibilisation et l'Education Financières. Recommandation du Conseil.

http://www.oecd.org/fr/finances/education- financiere/35108663.pdf

Vale, I. (2004). Some notes on qualitative research in mathematics education - the case study. In I.Vale, \& J. Portela, Journal ESEVC (pp 171-202). Viana do Castelo: School of Education of Viana do Castelo 